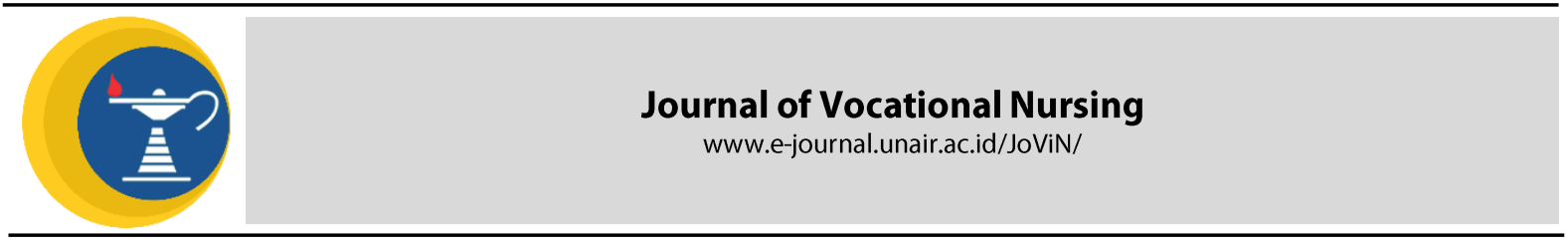

\title{
COMMUNICATION AND SELF-CONCEPT OF CHILDREN WITH DEAF AND SPEECH IMPAIRED
}

\author{
Eko Mulyadi', Nelyta Oktavianisya², Ulva Puspaningrum ${ }^{3}$
}

Research Report

1,2,3Nursing Department, Fakultas IImu Kesehatan, Universitas Wiraraja

\section{ABSTRACT}

Introduction: The communication and interaction is the essence of every human as a social being. But, normal communications is not realyzed by the deaf speaking children. Deaf and speech impaired children affect self-concepts that affect communication. Where it will caused them to become inferior or have less confident. The confidence is begins through the formation of self-concept which formed from the experiences in their social interactions. This study aims to find the description of the communication and self-concept of the deaf and speech impaired children in SLB Darma Wanita Sumenep. Methods: This study used qualitative as a research methode with phenomenology approach. Respondents in this study are students of SLB Darma Wanita Sumenep who deaf and speech impaired start on birth. The sampling technique is used purposive sampling counted 10 respondents. The data collected by observation and in-depth interviews of respondents. The data were analyze with triagulation of the interview, key person, and observation. Results: Based on the results of this study, known that between the deaf speaking children and the normal people have problems in terms of understanding the symbols and sentences that there not regularly, so they often occur discommunication. The self-concept of deaf speaking children is tend to be shy with the opposite gender, less open with new people, but they have a high spirits for they futures. They need encouragement to socialize with new people and other normal people. It can make their self-concept and self-confidence can be better. Conclusion: The communication deaf and speech impaired children experience obstacles in sending or receiving messages due to interference in understanding the symbols and writing that are given.

\section{ARTICLE INFO}

Recived 20 October 2020

Accepted 27 October 2020

Online 29 October 2020

${ }^{*}$ Correspondence:

Eko Mulyadi

*Email:

eko.wiraraja@gmail.com

\section{Keywords:}

Communication, Self Concept, the Deaf Speaking Child

\section{INTRODUCTION}

Communicating will help each individual to gather the desired information, provide affection or even cause hostility and contention. As with people who are deaf, they also need communication with other people. Every aspect of his life will always be in touch with other people, both deaf and other people who have perfect senses (Illahi.A.K, dkk, 2009).

children who are hearing impaired or deaf, the child cannot build or develop the ability to communicate from the imitation process of their environment. Moreover, for children who are born with hearing deafness, they cannot hear and cannot imitate their parents. Children know the caress of affection given by his parents only through helping hands, the eyes and expressions of his parents. Deafness from birth is what causes children not to get imitated voices, resulting in hearing loss.

Deaf children who experience obstacles in communication will also affect the child's psychological condition. Lack of hearing may lead to low self-esteem or lack of confidence when dealing with other people. Self-confidence itself begins with the formation of a self-concept that is formed from one's experiences in interacting with others (Suranto, 2007). Deaf girls who were confident and frequently asked for clarifications or who were comfortable playing alone tended to achieve good relationships with hearing peers. In contrast, deaf boys' relationships with hearing peers benefited mostly from the boys' ability to perform well in sports. (Martin \& Bat-Chava, 2003). The results of a survey conducted by WHO in 2015 said that more than $5 \%$ (360 million) of the world's 
population were deaf where 328 million were adults and 32 million were children, this proves that the number of hearing impairment in the world is still very high (WHO, 2017). In Indonesia alone, the prevalence of deaf people in 2012 was around 223,655 people or around $10.52 \%$ of the total people with disabilities in Indonesia.

\section{MATERIALS AND METHODS}

This study uses a qualitative research design with a phenomenological approach to understand the phenomena that occur in deaf and children in a holistic and descriptive manner in the form of words and language. The research was started from April to May 2017. The research variables were communication and self-concept. The sample used in this study were deaf children who attended school at SLB Darma Wanita Sumenep in the 2016-2017 school year, totaling 10 students with the Purpose Sampling technique. The selected informants were deaf children who had a severe deafness scale and also experienced speech impairment, aged 15 to 25 years. All informants were children with hearing impairment since birth, consisting of 2 boys and 8 girls. The data were processed using the data triagulation method. The variables in this study were the communication and self-concept of children with speech hearing hearing impairment in SLB Darma Wanita Sumenep.

\section{RESULTS}

1. The Communication Deaf and Speech Impaired Childrens

\section{a. Used Non Verbal Lenguage.}

The results of the interview revealed that children with hearing impairment had difficulty communicating with other children. they communicate with others using gestures or sign language. They reveal that communication with normal people is much more difficult than other speech-impaired people, they are not used to body language, gestures, symbos. The sign language that they do by using hand gestures which become symbols between deaf children uses terms that they already understand one another. From the results of in-depth interviews conducted with informants, the following statement was obtained: "I can't talk to friends, students have deaf friends, I want to talk to friends with sign language." (Other friends can't speak either, at school there are friends who are deaf too, I speak using sign language). (Date 20 April 2017 R9; line: 38,42,48).

From the results of observations made by the researcher on the informants, it was found that deaf children always use nonverbal language, namely by using gestures in which they use hand gestures to signal the sentence they want to convey. Speech deaf children have a speed in conveying messages using sign language to their friends, and so do their peers who use hand gestures to answer their messages. Meanwhile, from the results of the interview with the teaching teacher, the following statements were obtained: "Well for them, the communication is like that sometimes using hand signals, sometimes writing on paper, sometimes pointing directly to objects they just lack language vocabulary, so if there are words they don't understand, it will be difficult to explain."

Based on the description above, it can be concluded that the speed of delivery of sign language that is owned by deaf children is because they are used to using terms and words in convey messages using hand gestures.

\section{b. The Given Message Unreachable.}

The content in delivering messages is very influential in communicating with someone. In this case, deaf children have obstacles in arranging words and messages to be conveyed, but they are able to give a nonverbal impression. more natural in expressing the meaning of the message to be conveyed by using sign language. From the results of in-depth interviews conducted with informants, the following statement was obtained: "For writing messages through, there is finger communication with friends" (sending messages by writing, there is finger communication with friends) (April 20, 2017 R4; line: 56.60). "I can text with other people, I use books and pencils" (I often text with other people and sometimes use books and pencils to write messages). (R3 20 April 2017; line: 58.62).

From the results of observations made by researchers on informants, it was found that deaf children in writing messages through writing were still not good. Where seen from the way of writing the message or sentence written by the deaf child, the sentence was not well structured. The wording in interpreting it must be read from back to front. Like a few paragraphs of the story below: "At night, I want to pray maghrib until I eat until it's finished, today night I want to play my cellphone until 10:00 am I have to go home to sleep straight away. Until I wake up, I pray at dawn until it's finished, today morning at 7.30 I wake up to the bathroom at 8.00 to go to school". (Tonight, I just finished praying maghrib after dinner, and I played on my cellphone until 10 at night before I got home and went straight to sleep then got up to pray Fajr, at $7.30 \mathrm{am}$ I wake up and take a shower at 8 am I arrive at school). (Date 21 April 2017 R10; line:1). 
Meanwhile, from the results of the interview with the teaching teacher, the following statements were obtained: "Well, they are still lacking in writing, the writing is still forward to back, because they are accustomed to using worded sign language words become easier, rather than having to write on paper."

Based on the description above, it can be concluded that the messages conveyed by deaf children through writing are still irregular and language translation must be understood per sentence. However, in using sign language they have a clearer sense of the multiplication.

c. Delivery and Receive Message Disruption of Deaf and speech Impaired Childrens.

When communicating, acceptance of the contents of a message is very important so that the recipient of the message can reply to the message the sender sent. The message conveyed by deaf children is usually difficult for the recipient to understand, because they cannot understand the sign language or the message they convey. Statement can be seen below: "Yes, there are those who don't understand my gesture". (April 20, 2017 R5, R2, R10, R1; line: $77,77,65,83)$. However, some of them said that they do not experience difficulties if they are accustomed to seeing and using sign language that they do every day. The statement can be seen below: "It's not difficult, my friends understand". (Date 20 April 2017 R7; line: 62).

From the results of observations made by researchers on informants, it was found that deaf children did not experience obstacles to communicate with others, but they had difficulty communicating with researchers and other people. This can be seen when they are confused and re-ask the meaning of the questions the researcher asked during the interview. Meanwhile, from the results of the interview with the teaching teacher, the following statements were obtained: "Well, if people who are used to talking to them will easily understand, like their family friends, but if it's new like you guys are definitely difficult, confused how to understand."

From the results of the discussion above, it can be explained that they experience problems in delivering messages to those who do not understand the sign language they often use. However, this does not happen to families or people with whom they communicate frequently such as close relatives, friends or close friends.

\section{Self Consep of Deaf and Speech Impaired Childrens}

a. Deaf and Speech Impaired Childrens Tending to the Shy to be Opposite Sex.
From the interview results, it was found that children with hearing impairment have a slightly lower self-confidence than other normal children. They lack the confidence to speak in front of many people and feel happier when they are with a hearing deaf friend. The statement can be seen below: "Not ashamed if usual". (Don't be shy if you just speak casually) (Date 20 April 2017 R8, R7, R9; line: 14,14,) "Not ashamed that we usually love our deaf children". (not ashamed because our fellow deaf children love each other). (April 20, 2017 R9, R4, R6; line: 24,24,20). But there are some of them who say they are embarrassed when speaking in front of many people, especially towards the opposite sex who is normal. The statement can be seen below: "Embarrassed by another guy, sad". (Date 20 April 2017 R5, R2; line: 28,24).

From the results of observations made by researchers on informants, it was found that deaf children felt cheerful and active during interviews but they were closed in telling various things and easily offended when talking to a fellow deaf friend. Meanwhile, from the results of interviews with the teaching teacher get a statement like the following: "Teaching them must be extra deck, isn't it different from other children in general, and if they don't want to teach them, it's hard to get them to want to study again. So you have to be really patient and have to be smart in looking for ideas so you can focus."

From the results of the above discussion, it can be concluded that the self-esteem of children with hearing impairment can still be considered low because of the limitations they have and are not open to new people, especially to the opposite sex.

b. Ideal Self of Deaf and Speech Impaired Childrens to Friend and Family.

Most of the informants felt that they were happy with their current situation. From the results of interviews conducted with informants, it was found that they accepted the limitations they have happily wholeheartedly, as evidenced by the statement which can be seen below: "I like to speak sign language with friends". (April 20, 2017 R3, R5, R6, R4, R9; line: 28,42,24,28,28).

From the results of observations made by researchers on informants, it was found that deaf children felt cheerful and active when conducting interviews, had good self-confidence but were difficult to open up to new people. They do not want to tell and explain in detail what the researcher asked when it was done Interview and they are only open to people they have known for a long time such as family or friends with hearing impairments. 
Meanwhile, from the results of the interview with the teaching teacher, the following statements were obtained: "Actually they are the same as us, well, just because they have limitations, well, they are embarrassed to talk or joke with new people, the number is that they are less open to new people, but for self-confidence and their enthusiasm is higher than us." From the results of the above discussion, it can be concluded that the informants are happy and are not ashamed of the shortcomings they currently have. But they do not trust new people to tell everything they feel.

\section{c. Deaf and Speech Impaired Childrens Hope} about Future.

Judging from the results of the interview, the answers given by the informants were very good, had high hopes and aspirations for their future even with their limitations. The statement can be seen below: "Nurse". (April 20, 2017 R1, R2, R8; line: 50,42,38). From the results of observations made on informants, most of them have high hopes of achieving their goals later, they have high enthusiasm and sincerity in their lives. Meanwhile, from the results of the interview with the teaching teacher, the statement was obtained: "If the problem of ideals must be the same, they also have the same aspirations as us." From the above discussion, it is very clear that their selfexpectations are very high even though they have limitations that may greatly influence their future.

\section{DISCUSSION}

1. The Communication Deaf and Speech Impaired childrens

a. Used Non Verbal Lenguage

The use of sign language is required for children with deaf and speech Impaired. The use of sign language by hand is difficult for most people to understand. So that the efforts made are improving the ability of speech-deaf children to compose words and load them in a movement or gesture that is easily understood and understood by those around them. "I can sign language with friends, my friends talk and sign language, I sign with other people "(I use sign language with friends, my friends speak sign language too, I also use sign language with other people) (April 20, 2017 R3;line: 40,44,50). This sign system has two types of components, one of which functions as a determinant or differentiator of meaning, while the other serves as a support. If these two components have been fulfilled, then the signal that the deaf child has can be said that the deaf child's ability to sign is very good(Permanarian Somad dan Tati Hernawati, 1996). Abu Ahmadi (2002), said that people's daily life cannot be separated from one another. With good signaling abilities, the relationship between deaf children and others and with other normal environments will certainly run smoothly(Abu Ahmadi, 1999). As stated by Rahma (2012), which states that deaf children usually find it difficult to interpret abstract words, for example: sincerity, tolerance, and responsibility. They usually will find it easier to interpret words that can be manifested by concrete objects or directly captured by other sense organs(Cahyaningrum, 2012). It is in line with what was stated by Illahi et al. (2009) in their research which stated that during their research, there were so many symbols that could be found. For those who are speech deaf, they communicate more by using sign language. So that the symbols used by them are an integral part of the sign language. However, there are also symbols that are not included in the SIBI, which is a way for people with hearing impairments to make the atmosphere more lively. So it can be seen that their use of symbols is not much different. They have agreed symbols and mean the same thing every time they are used(IIlahi.A.K, dkk, 2009).

\section{b. The Given Message Unreachable}

Correct sentence formation consists of subject, predicate, object and description. In contrast to speech hearing deaf children, the messages they convey are written in a reverse way, namely the messages are conveyed from back to front. "At night I want to pray maghrib until I eat until it's finished, tonight I want to play my cellphone until 10:00 PM, I have to go home, go straight to sleep until I wake up, morning prayer until it's finished, this morning at 7.30 PM I wake up until the bathroom at 8.00 AM leaves for school "(Tonight I just finished praying maghrib then had dinner, and I played my cellphone until 10 PM and went straight to sleep. I got up for Fajr prayer, at 7.30 AM I got up and took a shower, and I arrive at school at 8 am) (April 21, 2017, R10; line: 1 ).

This is in accordance with what Hamidah (2013) and Handayani (2013) said, in their research which states that several obstacles are found that generally occur in deaf children in writing sentences, including: sentences written irregularly or without structure, word placement less precise, so that the sentence becomes less understood. Where when the teacher gives instructions to write the meaning of the picture into a simple sentence, the child has not been able to write a sentence with a subject $(S)$ and predicate $(P)$ structure, for example the child is given a card "the picture of the father is eating", the child only writes it: " eating "," eating pictures "," sitting ", or" father ", the child cannot write them using the correct 
sentence structure(Hamidah, 2013)(Handayani et al., 2013).

c. Delivery and Receive Message Disruption of Deaf and speech Impaired Childrens

Communication between individuals is strongly influenced by the content of messages and the delivery of messages from respondents or other people who are unclear or unclear so that communication cannot run properly. According to Dafid K. Berlo (1960), explaining that good communication must fulfill the following elements: The source or communicator is the initiator or the person who first started the communication process as the person who delivered the message. For example, in this study, deaf children, researchers alone or their families. The main message or product of information is everything that will be conveyed from the sender to the recipient of the message(David K Berlo, 1960).

2. Self Consep of Deaf and Speech Impaired Childrens

a. Deaf and Speech Impaired Childrens Tending to the Shy to be Opposite Sex

Shame is generally owned by everyone and so is in deaf children, but the tendency to be ashamed of the opposite sex makes deaf children reluctant to socialize with others. Stuart and Sundeen (1998) say that the ideal self is an individual's perception of how he should behave based on certain personal standards, aspirations, goals or values(Stuart and Sundeen, 1998). Jannah.M, (2015) said that individuals have the position of assessing themselves every day(Jannah.M., 2015). According to Centi (1993) that an individual's assessment is how the individual feels about himself as the person he thinks about(Centi, 1993).

\section{b. Self Ideal of Deaf and Speech Impaired Childrens to Friend and Family \\ Based on the results of observations} made by researchers on informants, it was found that deaf children felt cheerful and active during interviews, had good self-confidence but did not want to be open to new people. They do not want to tell and explain in detail what the researcher asked during the interview. The characteristics of the personality aspects of deaf children which include: high curiosity, aggressive, high egocentric, less able to control oneself (impulsivity), low imagination, less stable emotions, has high anxiety, has dependence on others (his family), is less independent, likes to hang out with people he is close to, has an innocent nature, is simple and without nuance, is stubborn(Edja Sadjaah, 2005).

c. Deaf and Speech Impaired childrens Hope about future

Everyone must have high hopes and desires and the deaf child is no exception. The handicaps they have are not a deterrent to them dream like people in general. According to Jannah.M (2015), saying hope is the second dimension of self-concept. In addition to individuals having a set of views about who they are, individuals also have a set of other views, namely about the possibility of becoming what they are in the future. In short, individuals have expectations for themselves and these expectations are different for each individual(Jannah.M., 2015). In contrast to what Edja Sadjaah (2005) said about the characteristics of the personality aspects of deaf children, they are curious, aggressive, have high egocentricity, are less able to control themselves (impulsivity), have low imagination(Edja Sadjaah, 2005).

\section{CONCLUSION}

Communication Children with hearing hearing impairment experience obstacles in sending or receiving messages due to interference in understanding the symbols and writing that are given. So that the communication skills of deaf children must be improved by understanding the meaning of information by increasing vocabulary and the meaning of a word.The self-concept of speech impaired children tends to be shy about their opponentskind and less open to people they just met, but they have a lot of passion for the future. So that the formation of good attitudes must continue to be nurtured and developed from time to time so that the improvement of their selfconcept is getting better, by changing the way children think about the problems they face into a new way of thinking in seeing all things. When communication between each other and with others goes well, this will also improve the selfconcept in the child, starting from self-confidence, ideal self and even role of self in society.

\section{REFERENCES}

Abu Ahmadi. (1999). Psikologi sosial. Rineka Cipta. Agustiani,Hendriati. $2006 . \quad$ Psikologi Perkembangan: Pendekatan Ekologi Kaitannya Dengan Konsep Diri Dan Penyesuaian Diri Pada Remaja.Bandung: Refika Aditama Ahmadi, Abu. 2002. Psikologi Sosial (ed.2). Jakarta: Rianeka Cipta. 
Astuti, Ratna Dwi. 2014. Identifikasi Faktor-Faktor yang Memepengaruhi Konsep diri Siswa Sekolah Dasar negeri Mendungan 1 Yogyakarta. Yogyakarta: Universitas Negeri Yogyakarta.Skripsi Bungin, Burhan.2012. Analisa Data Penelitian Kualitatif. Jakarta: Raja Rafindo Persada.

Azizun Kurnia Illahi, Akhmad Muwafik Saleh, dan Y. A. R. (n.d.). Komunikasi Antarpribadi Murid Tuna Ganda Rungu Wicara dalam Penyesuaian Diri terhadap Lingkungan Sosial di Usia Remaja (Studi Interaksionisme Simbolik pada Murid Tuna Ganda Rungu Wicara SMALB Yayasan Putra Pancasila Malang). 4-36.

Bustono,Mardiati.1988. Diagnosis dalam Pendidikan. Jakarta: Depdikbud.

Cahyaningrum, R. K. (2012). Tinjauan Psikologis Kesiapan Guru Dalam Menangani Peserta Didik Berkebutuhan Khusus Pada Program Inklusi (Studi Deskriptif Di Sd Dan Smp Sekolah Alam Ar-Ridho). Educational Psychology Journal, 1(1), 110.

Cahyaningrum, Rahma Kartika.2012. Tinjauan Psikologis Kesiapan Guru dalam Menangani Peserta Didik Berkebutuhan Khusus pada Program inklusi (Studi Deskriptif di SD dan SMP Sekolah Alam Ar-Ridho.

http://journal.unnes.ac.id/sju/index.php/ ep. diakses tanggal 14 Januari 2017.

Carpenito, L.J (2000). Diagnosa Keperawatan Aplikasi dalam Praktek Klinis. Jakarta: EGC.

Centi, J. P. (1993). Mengapa Rendah Diri? Kansius.

David K Berlo. (1960). The process of communication; an introduction to theory and practice. Rinehart and Winston.

Desmita. 2014. Psikologi Perkembangan Peserta Didik (Panduan bagi Orang Tua dan Guru dalam Memahami Psikologi Anak SD,SMP,SMA). Bandung: Remaja Rosdakarya.

Edja Sadjaah. (2005). Pendidikan Bahasa Bagi Anak Gangguan Pendengaran Dalam Keluarga. Departemen Pendidikan Nasional RI.

Efendi, Asfan. 2009. Persepsi Pasien tentang Komunikasi Terapeutik Perawat dalam Melaksanakan Asuhan Keperawatan di IRD RSUD dr.H.Moh.Anwar Sumenep. Skripsi.

Effendy, Uchjana Onong. 2007. Ilmu,Teori dan Falsafat Komunikasi. Bandung: PT.Citra Aditya Bakti.

Hamidah, I. (2013). Penerapan Metode Demonstrasi dalam Pembelajaran Bahasa
Indonesia untuk Meningkatkan Kemampuan Menulis Kalimat Sederhana Pada Siswa Tunarungu. Jassi Anakku, 12(1), 1-10.

Hamidah, Ida. 2013. Penerapan Metode Demonstarsi dalam Pembelajaran Bahasa Indonesia untuk Meningkatkan Kemampuan Menulis Klimat Sederhana pada Siswa Tunarungu. Tasikmalaya: Jassi_Anakku, Volume 2: Nomer 2 Tahun 2013

Handayani, Fitri.dkk. 2013. Meningkatkan Kemampuan Menulis Kalimat melalui Media Gambar bagi Anak Tunarungu.

Handayani, F., Sumekar, G., \& Kasiyati. (2013). MENINGKATKAN KEMAMPUAN MENULIS KALIMAT MELALUI MEDIA GAMBAR BAGI ANAK TUNARUNGU. 2(1), 311-322.

Hurlock, Elizabeth B. 2015. Perkembanagan Anak (edisi keenam jilid 1). Jakarta: Erlangga.

Hurlock, Elizabeth B. 2015. Perkembanagan Anak (edisi keenam jilid 2). Jakarta: Erlangga.

http://www..depkes.go.id//IndonesiaNasional. pdf. diakses pada Januari 16, 2017.

http://ejournal.upn.ac.id/index.php/jupekhu. diakses tanggal 21 Mei 2017.

Illahi.A.K, dkk. 2009. Komunikasi Antarpribadi Murid Tuna Ganda Rungu Wicara Dalam Penyesuaian Diri terhadap Lingkungan Sosial Usia Remaja ( Studi Interaksionisme Simbolik Pada Murid Tuna Ganda R.

Jannah.M. (2015). Kecemasan Karir ditinjau dari Konsep Diri dan Dukungan Sosial pada Mahasiswa Semester Akhir S1 UIN Sunan Kalijaga Yogyakarta. UIN.

Martin, D., \& Bat-Chava, Y. (2003). Negotiating deaf-hearing friendships: coping strategies of deaf boys and girls in mainstream schools. Child: Care, Health and Development, 29(6), 511-521. https://doi.org/10.1046/j.13652214.2003.00371.x

Martin, D., \& Bat-Chava, Y. (2003). Negotiating deaf-hearing friendships: coping strategies of deaf boys and girls in mainstream schools. Child: Care, Health and Development, 29(6), 511-521. https://doi.org/10.1046/j.13652214.2003.00371.x

Permanarian Somad dan Tati Hernawati. (1996). Ortopedagogik Anak Tunarungu. Depdikbud RI.

Stuart and Sundeen. (1998). Buku Saku Keperawatan Jiwa. Jakarta: EGC. 